\title{
Phaeospirillum chandramohanii sp. nov., a phototrophic alphaproteobacterium with carotenoid glycosides
}

\author{
Correspondence \\ Ch. V. Ramana \\ r449@sify.com \\ or \\ sasi449@yahoo.ie
}

\author{
P. Anil Kumar, ${ }^{1}$ T. N. R. Srinivas, ${ }^{1}$ S. Takaichi, ${ }^{2}$ T. Maoka, ${ }^{3}$ Ch. Sasikala ${ }^{1}$ \\ and Ch. V. Ramana ${ }^{4}$
}

${ }^{1}$ Bacterial Discovery Laboratory, Centre for Environment, Institute of Science and Technology, J. N. T. University, Kukatpally, Hyderabad 500 085, India
${ }^{2}$ Nippon Medical School, Department of Biology, Kosugi-cho, Nakahara, Kawasaki 211-0063, Japan

${ }^{3}$ Institute for Production Development, Shimogamo-morimoto-cho, Sakyo, Kyoto 606-0805, Japan

${ }^{4}$ Department of Plant Sciences, School of Life Sciences, University of Hyderabad, PO Central University, Hyderabad 500 046, India

\begin{abstract}
A Gram-negative, spiral-shaped, phototrophic, purple non-sulfur bacterial strain, designated $\mathrm{JA} 145^{\top}$, was isolated from a freshwater habitat. Cells of strain $\mathrm{JA} 145^{\top}$ were motile by means of a monopolar flagellum. Intracellular photosynthetic membranes were of the stacked type.

Bacteriochlorophyll $a$ and the carotenoid lycopene and its glucosides were present as photosynthetic pigments. There was no vitamin requirement for strain $\mathrm{JA} 145^{\top}$. The predominant cellular fatty acids were $\mathrm{C}_{16: 1} \omega 7 c / \mathrm{C}_{16: 1} \omega 6 c(22.24 \%), \mathrm{C}_{16: 0}(22.97 \%)$ and $\mathrm{C}_{18: 1} \omega 7 c$ (43.24\%). Phylogenetic analysis based on 16S rRNA gene sequences showed that strain $\mathrm{JA} 145^{\top}$ clustered with species of the genus Phaeospirillum, in the class Alphaproteobacteria. The highest sequence similarities of strain $\mathrm{JA} 145^{\top}$ were found with the type strains of Phaeospirillum fulvum (96.12\%) and Phaeospirillum molischianum (96.19\%). Based on the 16S rRNA gene sequence analysis and the morphological and physiological characteristics, strain $\mathrm{JA} 145^{\top}$ is considered to represent a novel species, for which the name Phaeospirillum chandramohanii sp. nov. is proposed. The type strain is $\mathrm{JA} 145^{\top}\left(=\mathrm{JCM} 14933^{\top}=\mathrm{KCTC} 5703^{\top}=\mathrm{NBRC} 104961^{\top}\right)$.
\end{abstract}

The genus Phaeospirillum was created by the transfer of two species of the freshwater representatives of the genus Rhodospirillum that show marked physiological and phylogenetic differences (Imhoff et al., 1998a). The genus Phaeospirillum comprises two recognized species, Phaeospirillum fulvum and Phaeospirillum molischianum (Imhoff et al., 1998a). In this paper, based on phenotypic and phylogenetic analysis we propose a novel species of the genus Phaeospirillum, isolated from a freshwater reservoir in India, which has properties that were distinct from those of the recognized species of the genus Phaeospirillum.

Strain JA145 ${ }^{\mathrm{T}}$ was isolated from a water sample $(\mathrm{pH} 7.2$, $30{ }^{\circ} \mathrm{C}$ ), collected on 18 March 2007 from the freshwater reservoir at Mudasarlova, Visakhapatnam, India $\left(17^{\circ} 45^{\prime} \mathrm{N}\right.$

The GenBank/EMBL/DDBJ accession number for the 16S rRNA gene sequence of strain $\mathrm{JA} 145^{\top}$ is $\mathrm{AM} 779061$.

A phase-contrast micrograph of cells and whole-cell absorption and acetone spectra of strain $\mathrm{JA} 145^{\top}$ and a table giving the ${ }^{1} \mathrm{H}$ NMR spectral data for hydroxylycopene $\beta$-D-glucoside in $\mathrm{CDCl}_{3}$ are available as supplementary material with the online version of this paper. $83^{\circ} 17^{\prime} \mathrm{E}$ ). Two purple non-sulfur bacteria (strains JA143 ${ }^{\mathrm{T}}$ and $\mathrm{JA} 145^{\mathrm{T}}$ ) were isolated from photolithoheterotrophic enrichments obtained from the water sample during a study of the diversity of cultured purple anoxygenic phototrophic bacteria. Isolation of strain $\mathrm{JA} 145^{\mathrm{T}}$ was performed as described previously for strain $\mathrm{JA}_{143}{ }^{\mathrm{T}}$ (Rhodospirillum sulfurexigens; Anil Kumar et al., 2008b). Subsequent culturing, purification and characterization were done using a medium (Pfennig \& Trüper, 1974, 1989) supplemented with $\mathrm{Na}_{2} \mathrm{~S}_{2} \mathrm{O}_{3}(4 \mathrm{mM})$. Purification and polyphasic taxonomic studies (Srinivas et al., 2007) and spectral analysis (Anil Kumar et al., 2008a) were carried out as described previously. Utilization of organic compounds as carbon source/electron donors for phototropic growth was determined without any additional carbon source/electron donor in the presence of yeast extract $(0.02 \%, w / v)$. The concentrations of the compounds used were $0.1 \%, \mathrm{v} / \mathrm{v}$ (formic acid, propionate, butyrate, caproate, valerate, lactate, glycerol, methanol and ethanol), $0.3 \%$, w/v (other organic compounds tested) and $1 \mathrm{mM}$ sodium benzoate. For the determination of sulfur sources, 
$\mathrm{MgSO}_{4} .7 \mathrm{H}_{2} \mathrm{O}$ was replaced by $\mathrm{MgCl}_{2} .5 \mathrm{H}_{2} \mathrm{O}$; sulfur sources $\left[\mathrm{Na}_{2} \mathrm{~S} .9 \mathrm{H}_{2} \mathrm{O}, \mathrm{Na}_{2} \mathrm{~S}_{2} \mathrm{O}_{3}\right.$, sodium thioglycolate, cysteine and $\mathrm{MgSO}_{4} \cdot 7 \mathrm{H}_{2} \mathrm{O}$ (all at $1 \mathrm{mM}$ )] were added to the medium. Nitrogen source utilization was determined by replacing ammonium chloride with various nitrogen sources $(0.068 \%, \mathrm{w} / \mathrm{v})$. The requirement for vitamins was determined using different vitamins $\left[\mu \mathrm{g}^{-1}\right.$ : biotin (100), thiamine (300), niacin (350), p-aminobenzoate (200), pyridoxal phosphate (100), pantothenate (100), inositol (100) and $B_{12}$ (20)], both singly and in combination. Negative controls did not have any of the vitamins or yeast extract. One control was supplemented with yeast extract alone. $\mathrm{NaCl}$ tolerance was determined by adding various concentrations of $\mathrm{NaCl}(0.05,0.1,0.5,1,2,3,4,5,6,7,8,9$, $10 \%)$ and also without $\mathrm{NaCl}$ in the medium. Chemotrophic growth was determined by growing the cultures in Erlenmeyer flasks placed in an orbital shaker in the dark and at $30{ }^{\circ} \mathrm{C}$. Microaerobic growth was tested by growing the cultures in agar dilution tubes without airtight stoppers. Diazotrophy of the culture was determined as growth under a nitrogen atmosphere by repeated subculturing for four times. Carotenoid composition was analysed by using $\mathrm{C}_{18}$-HPLC (Takaichi et al., 2001). After purification of carotenoids using silica gel and DEAEToyopearl column chromatography, and $\mathrm{C}_{18}$-HPLC, they were identified based on spectral data (Takaichi et al., 2001). Fatty acid methyl esters were prepared, separated and identified according to the instructions for the Microbial Identification System (Microbial ID; MIDI; Agilent: 6850) (Sasser, 1990) at the Royal Research Laboratories, Secunderabad, India.

Genomic DNA was extracted and purified according to the method of Marmur (1961) and the $\mathrm{G}+\mathrm{C}$ content of the DNA was determined by HPLC (Mesbah et al., 1989). DNA was extracted and purified by using a Qiagen genomic DNA extraction kit. PCR amplification and 16S rRNA gene sequencing were performed as described previously (Imhoff et al., 1998b). Recombinant Taq polymerase was used for PCR, which was initiated with the primers $5^{\prime}$ GTTTGATCCTGGCTCAG-3' and 5'-TACCTTGTTACGACTTCA-3' (Escherichia coli positions 11-27 and 14891506 , respectively). Sequences were obtained by using cycle sequencing with a SequiTherm sequencing kit (Biozym) and the chain termination reaction (Sanger et al., 1977) with an automated laser fluorescence sequencer (Pharmacia). Next relatives and sequence similarities were determined by using NCBI-BLAST search (Altschul et al., 1990) and EzTaxon (Chun et al., 2007). For phylogenetic analysis, 16S rRNA gene sequences of representative type strains of Rhodospirillales (purple non-sulfur bacteria) species and of strain JA145 ${ }^{\mathrm{T}}$ were aligned using the program CLUSTAL_X (Thompson et al., 1997) (multiple alignment option). The alignment was checked manually using BioEdit software (Hall, 1999) and the file was saved in PHYLIP format. The PhyML online version (Guindon et al., 2005) was used for phylogenetic calculations. The maximum-likelihood tree was calculated using the GTR model (Lanave et al., 1984), based on the hill-climbing principle and estimated proportion of invariable sites, as well as the Gamma distribution parameter. The parameters in the program PhyML were as follows: input sequences are interleaved, with 100 nonparametric bootstrap analysis, GTR model of nucleotide substitution, 4 substitution rate categories, fixed Gamma distribution parameter $(\mathrm{alpha}=2.00)$.

Cells of strain JA145 ${ }^{\mathrm{T}}$ were Gram-negative, spiral shaped, $0.8-1.0 \mu \mathrm{m}$ wide and $4-8 \mu \mathrm{m}$ long and one single turn is 6-8 $\mu \mathrm{m}$ long; cells also formed long chains and the length of the chains could reach up to $30 \mu \mathrm{m}$ or more (see Supplementary Fig. S1, available in IJSEM Online). The cells multiply by binary fission, are motile by means of a monopolar flagellum and intracellular photosynthetic membranes were are of the stacked type. Strain JA145 was able to grow photo-organoheterotrophically [anaerobically in the light $(2400 \mathrm{~lx})$ with pyruvic acid $(0.3 \%, \mathrm{w} / \mathrm{v})]$. Photolithoautotrophy [anaerobically in the light $(2400 \mathrm{~lx})$ with $\mathrm{Na}_{2} \mathrm{~S} .9 \mathrm{H}_{2} \mathrm{O}, \mathrm{Na}_{2} \mathrm{~S}_{2} \mathrm{O}_{3} .5 \mathrm{H}_{2} \mathrm{O}(1.0 \mathrm{mM})$ and $\mathrm{NaHCO}_{3}$ $(0.1 \%, \mathrm{w} / \mathrm{v})$ ], chemolithoautotrophy [aerobically in the dark with $\mathrm{Na}_{2} \mathrm{~S}_{2} \mathrm{O}_{3} .5 \mathrm{H}_{2} \mathrm{O}(1.0 \mathrm{mM})$ and $\mathrm{NaHCO}_{3}(0.1 \%$, $\mathrm{w} / \mathrm{v})$ ], chemoorganoheterotrophy [aerobically in the dark with pyruvate $(0.3 \%, \mathrm{w} / \mathrm{v})]$ and fermentative growth [anaerobically in the dark with pyruvate $(0.3 \%, w / v)$ ] could not be demonstrated. Organic substrates utilized for photoorganoheterotrophy (Table 1) include acetate, butyrate, valerate, caproate, caprylate, crotonate, pyruvate, malate, fumarate and mannitol. Those substrates that could not be utilized by strain $\mathrm{JA} 145^{\mathrm{T}}$ include formate, propionate, glycolate, benzoate, tartrate, lactate, succinate, citrate, D-glucose, D-fructose, glutamate, arginine, aspartate, sorbitol, glycerol, methanol, ethanol, propanol, peptone, yeast extract and Casamino acids. Strain JA145 ${ }^{\mathrm{T}}$ could utilize ammonium chloride and dinitrogen as nitrogen sources, whereas glutamate, glutamine, urea, nitrate and nitrite did not support growth. Growth factors were not required for growth of strain $\mathrm{JA} 145^{\mathrm{T}}$. Sulfate, sulfite, elemental sulfur and sulfide are used as sulfur sources by the strain. $\mathrm{NaCl}$ was not required for growth of strain JA145 ${ }^{\mathrm{T}}$. The $\mathrm{pH}$ range for growth of strain $\mathrm{JA} 145^{\mathrm{T}}$ was 6.5-8.0, with an optimum at $\mathrm{pH}$ 7.0. The temperature range for growth was $25-35^{\circ} \mathrm{C}$, with optimum growth at $30{ }^{\circ} \mathrm{C}$. The colour of photosynthetically grown cell suspensions of the strain was brown-orange. The wholecell absorption spectrum (Supplementary Fig. S2a, in IJSEM Online) of strain JA145 ${ }^{\mathrm{T}}$ showed absorption maxima at $383,407,461,491,527,593,803,860 \mathrm{~nm}$, confirming the presence of bacteriochlorophyll $a$ and the absorption spectrum (Supplementary Fig. S2b, in IJSEM Online) for pigments extracted with acetone gave absorption maxima at 448,473 and $506 \mathrm{~nm}$, indicating the presence of carotenoids. The carotenoid composition of strain $\mathrm{JA} 145^{\mathrm{T}}$, as determined by using HPLC analysis, was lycopene $(10 \%)$, hydroxylycopene $(77 \%)$, hydroxylycopene glucoside $(11 \%)$, and dihydroxylycopene diglucoside $(2 \%)$. They were identified based on an absorption spectrum $(293,361,444,468,499 \mathrm{~nm})$ of the $\mathrm{C}_{18}$-HPLC 
Table 1. Differential characteristics of species of the genus Phaeospirillum

Taxa: 1, strain JA145 ${ }^{\mathrm{T}}$ (Phaeospirillum chandramohanii sp. nov.); 2, Phaeospirillum fulvum; 3, Phaeospirillum molischianum. Most of the data for reference species 2 and 3 were taken from Imhoff (2005a, b); carotenoid composition and fatty acid methyl ester analysis for species 1 and 3 was done in the authors' laboratory under identical conditions. All strains were motile and contain carotenoids: lycopene, hydroxylycopene, hydroxylycopene glucoside and dihydroxylycopene diglucoside. Organic substrate utilization was tested during photoheterotrophic growth. Pyruvate, fumarate, malate and caprylate were utilized by all the taxa. Arginine, citrate, glycerol and fructose were not utilized by any of the taxa. + , Substrate utilized or present; - , substrate not utilized or absent; $+/-$, variable in different strains; $(+)$, weak growth; $\mu$, growth under micro-oxic conditions; NA, information not available; ND, not determined/not detected.

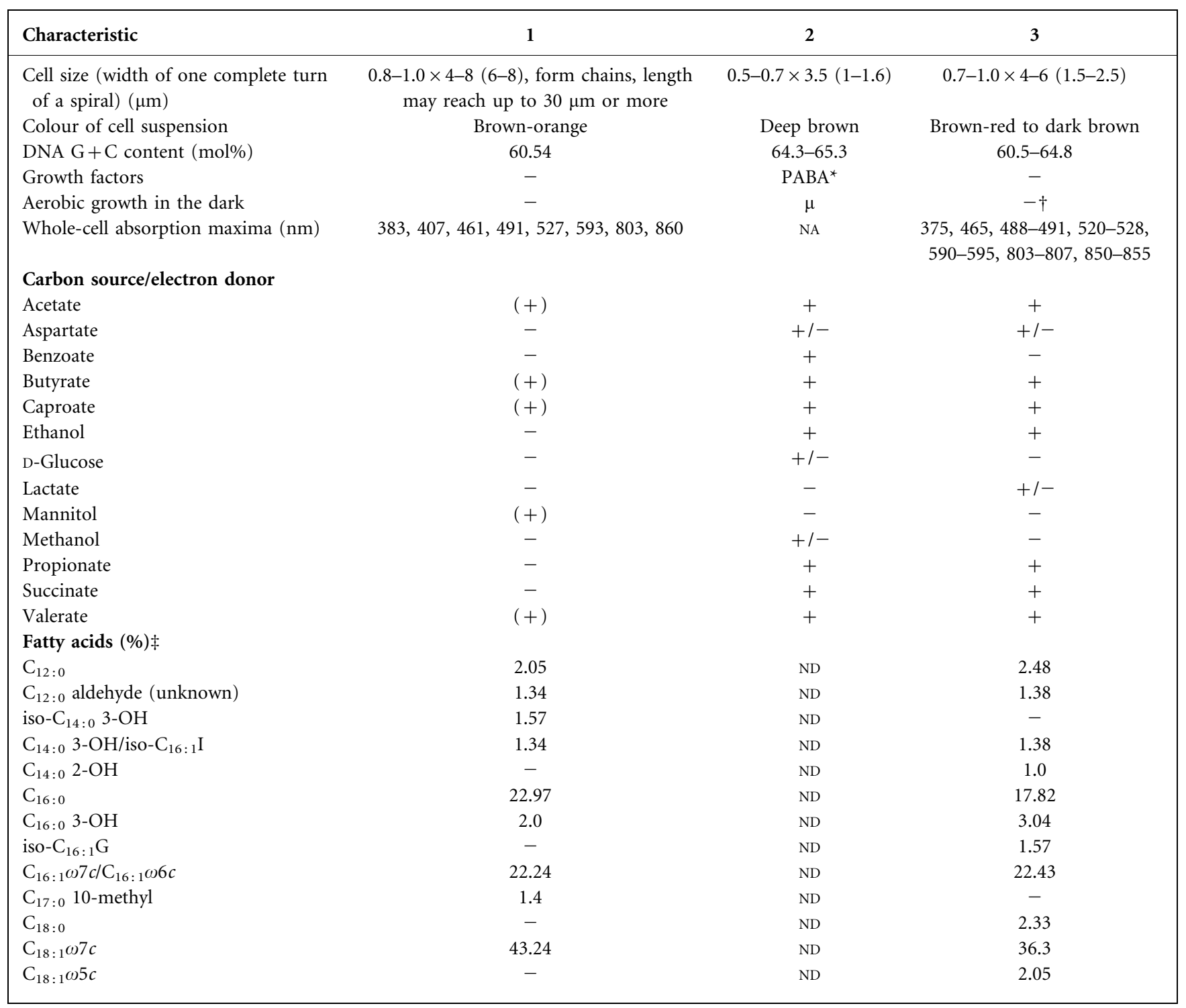

${ }^{\star}$ PABA, $p$-Aminobenzoic acid.

$\dagger$ Tested in our laboratory.

$\ddagger$ Fatty acids less than $1 \%$ were not considered.

eluent of methanol, the retention times on the $\mathrm{C}_{18}$-HPLC, and the relative molecular masses $(536,554,716$, and 896 , respectively), and the proton nuclear magnetic resonance spectrum (Supplementary Table S1, available in IJSEM Online; Takaichi et al., 2001). Carotenoids of the recognized species of Phaeospirillum, $P$. fulvum and $P$. molischianum, were reported to be lycopene, hydroxylycopene (rhodopin), dihydroxylycopene and polar carotenoid (Takaichi, 1999), but their identification was insufficient. The presence of lycopene glucosides is limited to a few bacterial species (Takaichi, 1999) and all the species of the genus Phaeospirillum have them. Whole-cell fatty acid 
analysis showed that the fatty acids $\mathrm{C}_{16: 1} \omega 7 c / \mathrm{C}_{16: 1} \omega 6 c$ $(22.24 \%), \mathrm{C}_{16: 0}(22.97 \%)$ and $\mathrm{C}_{18: 1} \omega 7 c(43.24 \%)$ predominated in strain JA145 ${ }^{\mathrm{T}}$ (Table 1).

The DNA base composition of strain JA145 ${ }^{\mathrm{T}}$ was $60.54 \mathrm{~mol} \%$ (by HPLC). The phylogenetic relationship of strain $\mathrm{JA} 145^{\mathrm{T}}$ to other purple non-sulfur bacteria was examined based on 16S rRNA gene sequences (1400 bases). The data obtained revealed that the new isolate clustered with the type strains of Phaeospirillum species, but were distinct from other genera of purple non-sulfur bacteria. The highest sequence similarities of strain $\mathrm{JA} 145^{\mathrm{T}}$ were with the type strains of $P$. fulvum (96.12\%) and P. molischianum $(96.19 \%)$ (Fig. 1). Strain JA145 ${ }^{\mathrm{T}}$ also showed clear phenotypic differences with other Phaeospirillum species (Table 1) that justify the description of strain $\mathrm{JA} 145^{\mathrm{T}}$ as representing a novel species, for which the name Phaeospirillum chandramohanii sp. nov. is proposed.

\section{Description of Phaeospirillum chandramohanii sp. nov.}

Phaeospirillum chandramohanii (chan.dra.mo.ha' ni.i. N.L. masc. gen. n. chandramohanii of Chandramohan, named after Dr D. Chandramohan, an Indian marine microbiologist, who has played a crucial role in transforming microbiological research at the National Institute of Oceanography, India into technologically rewarding activities).

Cells are Gram-negative, spiral-shaped, $0.8-1.0 \mu \mathrm{m}$ wide and $4-8 \mu \mathrm{m}$ long; one single turn is $6-8 \mu \mathrm{m}$ long. Cells also form long chains of more than $30 \mu \mathrm{m}$ in length, are motile with monopolar flagella and divide by binary fission. Growth occurs under anaerobic conditions in the light (photoorganoheterotrophy). Internal photosynthetic membranes are of the stacked type. The colour of the phototrophic culture is brown-orange. The in vivo absorption spectrum of intact cells in sucrose exhibits maxima at 383, 407, 461, 491, 527, 593, 803 and $860 \mathrm{~nm}$. Bacteriochlorophyll $a$ and the carotenoid lycopene and its glucosides are the photosynthetic pigments. Mesophilic $\left(30{ }^{\circ} \mathrm{C}\right)$ and has a pH optimum of 7.0 for optimal growth. Photoorganoheterotrophy with a few organic compounds is the only mode of growth. Pyruvate, crotonate, malate and fumarate are good carbon sources. Growth also occurs on acetate, butyrate, valerate, caproate, caprylate and mannitol. Photolithoautotrophic, chemolithoautotrophic,

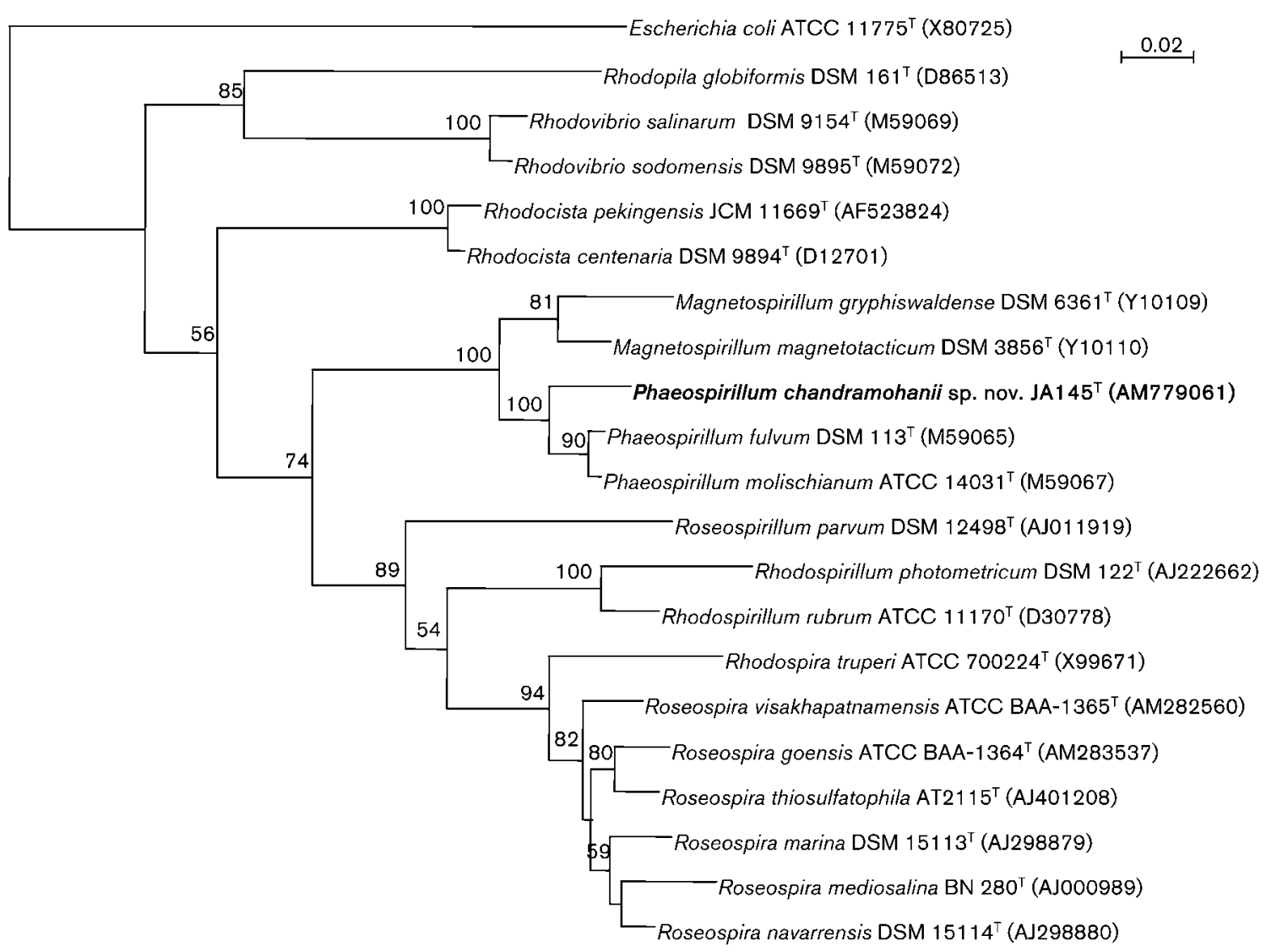

Fig. 1. Phylogenetic tree based on $16 \mathrm{~S}$ rRNA gene sequences showing the relationship of strain $\mathrm{JA} 145^{\top}$ within the order Rhodospirillales. The tree was constructed using the PhyML program. Numbers at nodes are bootstrap percentages. Values $<50 \%$ are not shown. Bar, 2 nucleotide substitutions per 100 nucleotides. 
chemoorganoheterotrophic and fermentative growth could not be demonstrated. Sulfate, sulfite, elemental sulfur and sulfide are used as sulfur sources. Growth factors are not required. Predominant fatty acids are $\mathrm{C}_{16: 1} \omega 7 c / \mathrm{C}_{16: 1} \omega 6 c$, $\mathrm{C}_{16: 0}$ and $\mathrm{C}_{18: 1} \omega 7 c$. The DNA G $+\mathrm{C}$ content of the type strain is $60.54 \mathrm{~mol} \%$ (by HPLC). Natural habitats are freshwater.

The type strain, JA145 ${ }^{\mathrm{T}}\left(=\mathrm{JCM} 14933^{\mathrm{T}}=\mathrm{KCTC} 5703^{\mathrm{T}}=\right.$ NBRC $\left.104961^{\mathrm{T}}\right)$, was isolated from a water sample from freshwater reservoir at Mudasarlova, Visakhapatnam, India.

\section{Acknowledgements}

The Department of Biotechnology, Government of India, is acknowledged for financial support. Facilities used under the DST FISTLevel2 are acknowledged.

\section{References}

Altschul, S. F., Gish, W., Miller, W., Myers, E. W. \& Lipman, D. J. (1990). Basic local alignment search tool. J Mol Biol 215, 403-410.

Anil Kumar, P., Srinivas, T. N. R., Sasikala, Ch. \& Ramana, Ch. V. (2008a). Allochromatium renukae sp. nov. Int J Syst Evol Microbiol 58, 404-407.

Anil Kumar, P., Aparna, P., Srinivas, T. N. R., Sasikala, Ch. \& Ramana, Ch. V. (2008b). Rhodospirillum sulfurexigens sp. nov., a phototrophic alphaproteobacterium requiring a reduced sulfur source for growth. Int J Syst Evol Microbiol 58, 2917-2920.

Chun, J., Lee, J.-H., Jung, Y., Kim, M., Kim, S., Kim, B. K. \& Lim, Y. W. (2007). EzTaxon: a web-based tool for the identification of prokaryotes based on $16 \mathrm{~S}$ ribosomal RNA gene sequences. Int J Syst Evol Microbiol 57, 2259-2261.

Guindon, S., Lethiec, F., Duroux, P. \& Gascuel, O. (2005). PHYML Online-a web server for fast maximum likelihood-based phylogenetic inference. Nucleic Acids Res 33, W557-W559.

Hall, T. A. (1999). BioEdit: a user-friendly biological sequence alignment editor and analysis program for Windows 95/98/NT Nucleic Acids Symp Ser 41, 95-98.

Imhoff, J. F. (2005a). Genus I. Rhodospirillum Molisch 1907, 24 ${ }^{\mathrm{AL}}$ emend. Imhoff, Petri and Süling 1998, 796. In Bergey's Manual of Systematic Bacteriology, 2nd edn, vol. 2, Part C, pp. 1-6. Edited by D. J. Brenner, N. R. Krieg, J. T. Staley \& G. M. Garrity. New York: Springer. Imhoff, J. F. (2005b). Genus V. Phaeospirillum Imhoff, Petri and Süling 1998, 796 ${ }^{\mathrm{VP}}$. In Bergey's Manual of Systematic Bacteriology, 2nd edn, vol. 2, Part C, pp. 32-33. Edited by D. J. Brenner, N. R. Krieg, J. T. Staley \& G. M. Garrity. New York: Springer.

Imhoff, J. F., Süling, J. \& Petri, R. (1998a). Reclassification of species of the spiral-shaped phototrophic purple non-sulfur bacteria of the
$\alpha$-Proteobacteria: description of the new genera Phaeospirillum gen. nov., Rhodovibrio gen. nov., Rhodothalassium gen. nov. and Phaeospirillum gen. nov. as well as transfer of Rhodospirillum fulvum to Phaeospirillum fulvum comb. nov., of Rhodospirillum molischianum to Phaeospirillum molischianum comb. nov., of Rhodospirillum salinarum to Rhodovibrio salinarum comb. nov., of Rhodospirillum sodomense to Rhodovibrio sodomensis comb. nov., of Rhodospirillum salexigens to Rhodothalassium salexigens comb. nov. and of Rhodospirillum mediosalinum to Roseospira mediosalina comb. nov. Int J Syst Bacteriol 48, 793-798.

Imhoff, J. F., Süling, J. \& Petri, R. (1998b). Phylogenetic relationships among the Chromatiaceae, their taxonomic reclassification and description of the new genera Thiocapsa, Halochromatium, Isochromatium, Marichromatium, Thiococcus, Thiohalocapsa and Thermochromatium. Int J Syst Bacteriol 48, 1129-1143.

Lanave, C., Preparata, G., Saccone, C. \& Serio, G. (1984). A new method for calculating evolutionary substitution rates. J Mol Evol 20, 86-93.

Marmur, J. (1961). A procedure for the isolation of deoxyribonucleic acid from microorganisms. J Mol Biol 3, 208-218.

Mesbah, M., Premachandran, U. \& Whitman, W. B. (1989). Precise measurement of the $\mathrm{G}+\mathrm{C}$ content of deoxyribonucleic acid by highperformance liquid chromatography. Int J Syst Bacteriol 39, 159-167.

Pfennig, N. \& Trüper, H. G. (1974). The phototrophic bacteria. In Bergey's Manual of Systematic Bacteriololgy, 8th edn, pp. 24-75. Edited by R. E. Buchanan \& N. E. Gibbons. Baltimore: Williams \& Wilkins.

Pfennig, N. \& Trüper, H. G. (1989). Family Chromatiaceae. In Bergey's Manual of Systematic Bacteriology, vol. 3, pp. 1637-1653. Edited by J. T. Staley, M. P. Bryant. N. Pfennig \& J. G. Holt. Baltimore: Williams \& Wilkins.

Sanger, F., Nicklen, S. \& Coulson, A. R. (1977). DNA sequencing with chain terminating inhibitors. Proc Natl Acad Sci U S A 74, 5463-5467.

Sasser, M. (1990). Identification of bacteria by gas chromatography of cellular fatty acids, MIDI Technical Note 101. Newark, DE: MIDI Inc.

Srinivas, T. N. R., Anil Kumar, P., Sasikala, Ch. \& Ramana, Ch. V. (2007). Rhodovulum imhoffii sp. nov. Int J Syst Evol Microbiol 57, 228232.

Takaichi, S. (1999). Carotenoids and carotenogenesis in anoxygenic photosynthetic bacteria. In The Photochemistry of Carotenoids, pp. 3969. Edited by H. A. Frank, A. J. Young, G. Britton \& R. J. Cogdell. The Netherlands: Kluwer.

Takaichi, S., Maoka, T., Hanada, S. \& Imhoff, J. F. (2001). Dihydroxylycopene diglucoside diesters: a novel class of carotenoids from the phototrophic purple sulfur bacteria Halorhodospira abdelmalekii and Halorhodospira halochloris. Arch Microbiol 175, 161-167.

Thompson, J. D., Higgins, D. G., Gibson, T. J., Plewniak, F., Jeanmougin, F. \& Higgins, D. G. (1997). The CLUSTAL_X windows interface: flexible strategies for multiple sequence alignment aided by quality analysis tools. Nucleic Acids Res 25, 4876-4882. 